\title{
Notes on the Life History of Anaphia petiolata (Kröyer).
}

\author{
$\mathrm{By}$ \\ Marie V. Lebour, M.Sc., \\ Assistant Lecturer in Zoology, Leeds University. \\ Temporary Naturalist at the Plymouth Labratory.
}

With Figures 1 to 3 in the Text.

IN the early summer of 1915 it was noticed that many medusæ brought in with the tow-nettings contained larval Pycnogonids in the manubrium and at the junction of manubrium and stomach. The medusæ specially noticed to contain them were Obelia sp., Cosmetira pilosella, Turris pileata, Stomotoca dinema and Phialidium hemisphericum. By far the greater number were in Obelia, although many were in Phialidium hemisphericum and Cosmetira pilosella. They were extremely abundant in June, after that became scarcer, and finally disappeared by October. On examination they were seen to be larval stages of Anaphia petiolata* (Kröyer), a Pycnogonid common in Plymouth Sound. The older larvæ sometimes were seen to cast their skins, so that the species could be easily recognised, although the fourth pair of walking legs were not fully developed. This is evidently the species described by Dogiel (1913) as Anoplodactylus pygmaeus, the life history of which he traces from its first entry into the Obelia hydroid to the older stages when it is ready to leave its host. The form he refers to as Anoplodactylus petiolatus occurring in cysts in Coryne with Phoxichilidium femoratum must be some other species, as his figures prove clearly that it differs from A. pygmaus, and also the colour is totally different (a bright pink, while the present form is a pale yellow). Dogiel believes he has proved that Anoplodactylus petiolatus and $A$. pygmaeus are different species from the difference in their life histories, and it is evident that he is dealing with two different species, but his $A$. petiolatus cannot be the same as our form, which is certainly identical with his A. pygmaus, and shows that Sars (1891) and Norman (1894) were right in regarding $A$. pygmoous as the young form of $A$. petiolatus (Kröyer).

* This is a synonym of Anoplodactylus petiolatus (Kröyer). See Norman, 1908, p. 202. 
Dogiel's account of the larval stages of $A$. pygmaus, together with the present discovery of the older larvæ in medusæ, shows a most interesting life history. According to him the very young larva hatches out of the egg (which contains very little yolk), leaves the protection of the father, and crawls on to the Obelia hydroid. In this early stage it has three appendages, the first the chelæ, the second and third with long threadlike ends which are used for attachment to the father directly after hatching. It immediately begins to burrow into one of the hydroid polyps, and once settled down there undergoes a metamorphosis, the second and third appendages atrophy, and three pair of walking legs develop. After several moults older larvæ appear, which are like the adults, except for the incompleteness of the last pair of walking legs, and these leave the hydroid and begin to live a free existence.

The stages found in the medusæ correspond to the larval stages after the second and third appendages have atrophied. The youngest stage seen corresponds with Dogiel's Stage IV with the three pair of walking legs indicated and the chelæ well stretched out in front, which are used for clinging firmly to the host. Dogiel has called attention to the fact that many larvæ do not succeed in entering the polyps, and have to undergo their development on and not in the hydroid, and now we find still another alternative for the larva. A large proportion of them, instead of entering a polyp, must in some way manage to enter a medusa. How they do this it is not possible at present to say. Possibly they cling to a medusa just as it is escaping from the colony, or perhaps they may get into a gonotheca before the liberation of the medusæ. One young larva in just the same stage as the youngest from a medusa was found amongst a colony of Obelia from Laminaria collected below the Laboratory. The occurrence of the same larva in various medusæ shows that it does not strictly keep to one species or genus of hydroid, although Obelia seems to be the favourite host.

The discovery that larval Pycnogonids are carried about by medusæ must have an important bearing on their means of dispersal, those individuals which are in the medusæ having much greater chances of life than those in the crowded area where the hydroid colony is situated. Pycnogonids swim feebly, and have not much in themselves to help in their distribution (see Calman, 1915, p. 6), but in the parasitic habits we have an important means of dispersal. Already H. Merton (1906) has found a species of nymphon ( $N$. parasiticum) living parasitically on the nudibranch Tethys leporina in the Mediterranean. H. Prell (1909) has found nymphon on Lucernaria (in this case eating the tentacles), now we find larval forms being carried about in medusæ. It is interesting to note that a young specimen of Endeis spinosus (Montagu) was twice found 
in the tow-nettings from outside the Breakwater, Plymouth, extended flat on the top of the bell of an Obelia medusa, and clinging to it. So beautifully was it balanced that the medusa could swim perfectly, although weighted by the Pycnogonid.

If medusæ and Pycnogonids are left together in a vessel, e.g. Anaphia petiolata or Endeis spinosus, it is nearly always found that the Pycnogonids are attracted towards the medusæ and cling to them. The only movement made by the young larvæ when taken from the medusæ is a strong waving of the chelæ, and if these come in contact with a medusa they cling tightly to it.
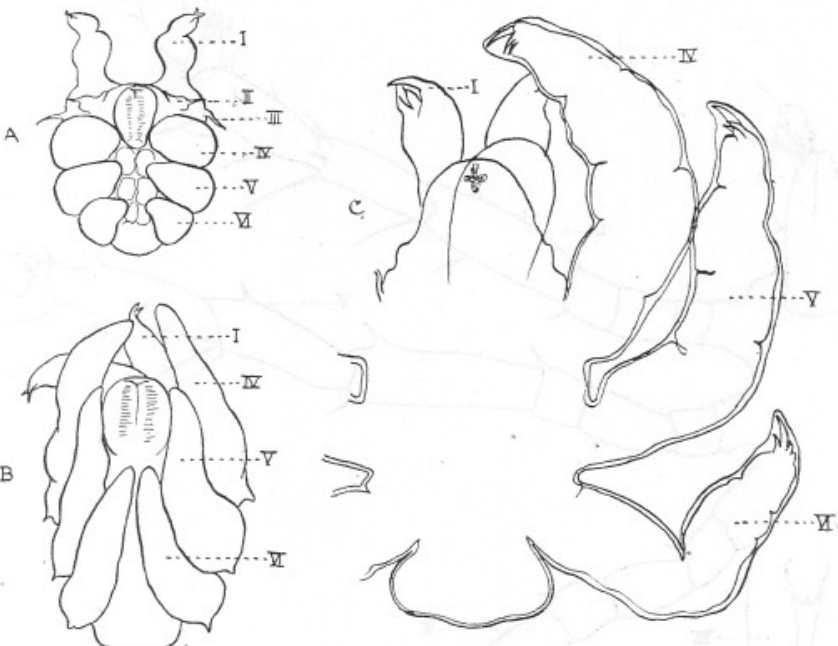

Fig. 1.-Larval stages of Anaphia petiolatus (Kröyer): $\times 60$. A. Youngest stage in Obelia medusa ; B. Later stage; C. Still later stage, the legs having been separated with needles. I-VI. The appendages. Ventral view.

The larva at all stages is of a pale yellow colour, and has its legs so folded that they pack into the smallest possible space. As many as four were found in one medusa, but usually there is only one. It grows rapidly, and the body elongates considerably together with a great lengthening of the legs. In the youngest stage found (Fig. 1, A) the legs (IV-VI) were short, roundish stumps, the alimentary canal extending into them and well into the chelæ. The chelæ were powerfully developed with strong claws; remains of the second and third larval appendages were seen as small hair-like protuberances. These, however, are often very difficult to see, and the drawing shows an exceptionally clear specimen. These appendages, although dwindling, persist until the larva has grown to nearly twice the size ; in this differing from Dogiel's observations, who describes them as disappearing almost at once. 
As the legs elongate a short spine is apparent at the angle of folding, but these soon disappear (Fig. 1, B). When considerably larger the larva resembles the adult, although still packed up tight. If the legs be unfolded the body is seen to be broad with the cephalic segment distinct, proboscis fairly long, the claws of the legs showing through the skin, and the last pair of legs and caudal segment appearing as a broad hind piece (Fig. 1, C). Yellow eyes have now appeared. This is the last larval

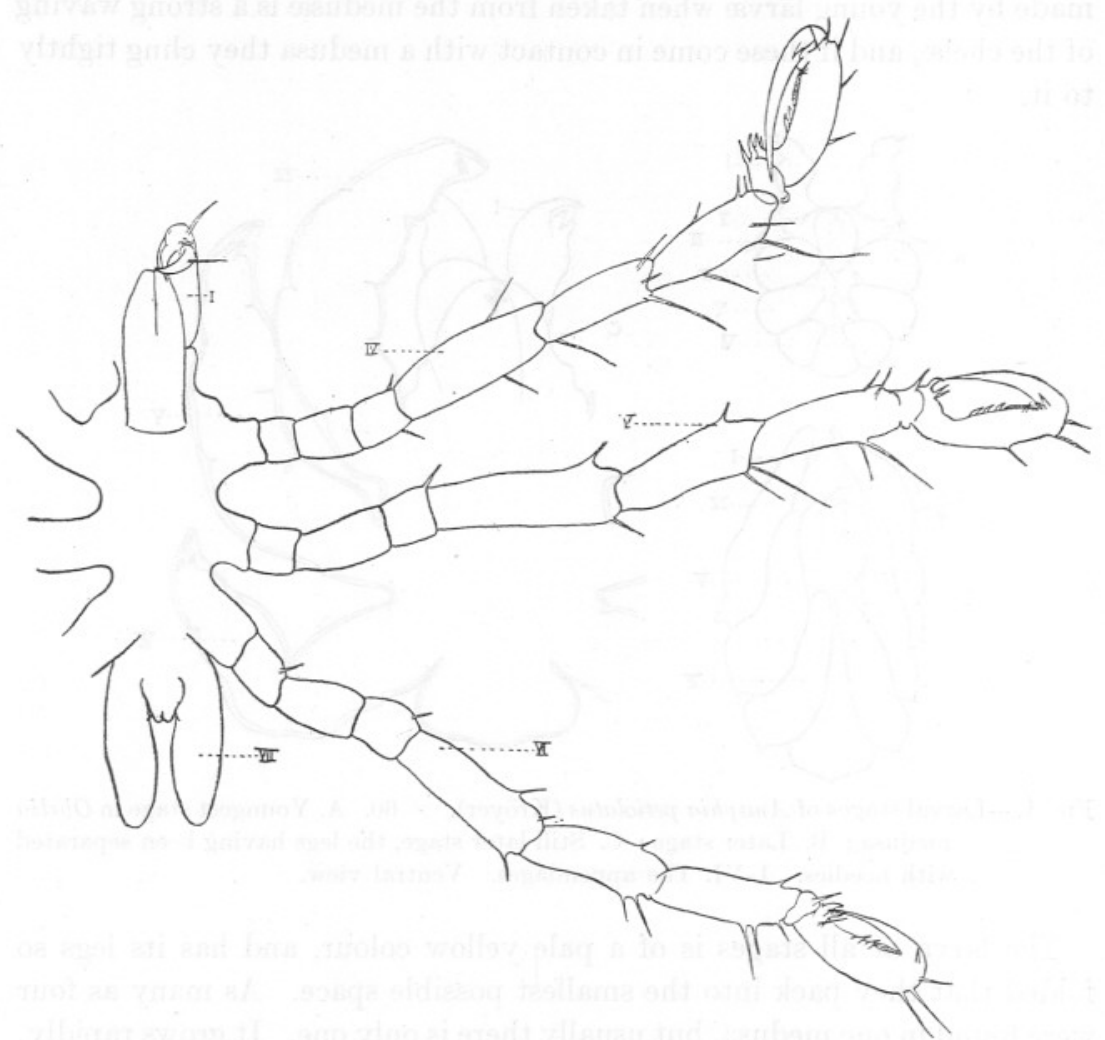

FIG. 2.-Young Anaphia petiolata (Kröyer) soon after emergence from the last larval skin. Lettering as before. $\times 47$.

stage, which shows the young Anaphia through the skin, and this form can often be seen with the young Anaphia emerging from it. This is in all essentials like the adult, but much smaller, and with the last pair of legs appearing as two stumps with a very short caudal segment in between them. When quite newly hatched it measures about $0.70 \mathrm{~mm}$. from the anterior end of the cephalic segment to the posterior end of the caudal segment (Fig. 2). The cephalic segment is very short, in fact the whole animal is exactly like the figures and descriptions of Anoplo- 
dactylus pygmaus (Hoek, 1881; Hodge, 1864). By comparing these young forms with older undoubted specimens of Anaphia petiolata (Kröyer), they correspond exactly with the exception of the length of the cephalic segment, which grows with the animal just as Canon Norman suggests (1894). The growth, however, appears to take place after the
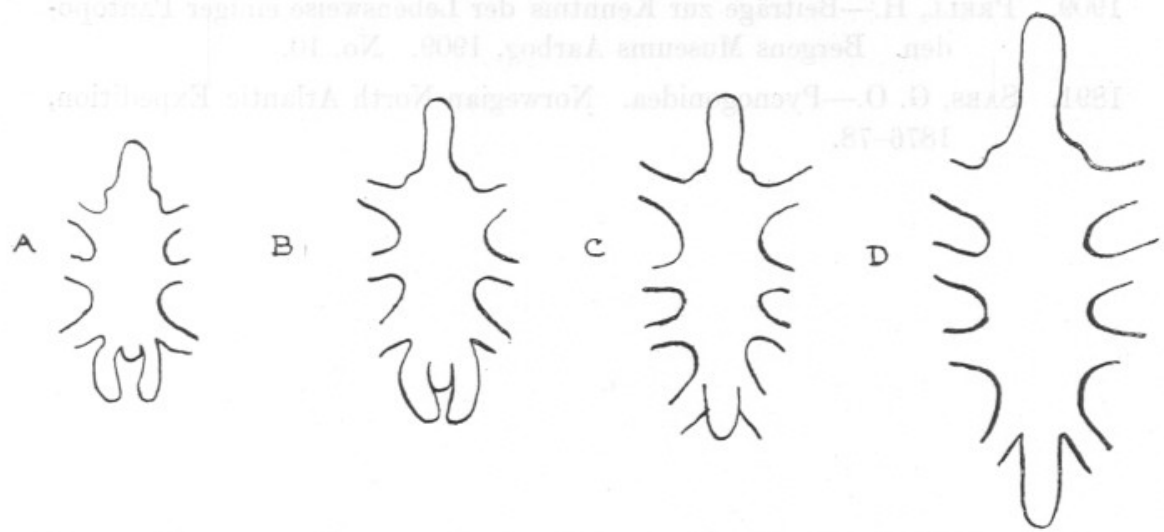

FIG. 3.-Diagram to show growth of cephalic segment. A. Length $0 \cdot 70 \mathrm{~mm}$, young Anaphia petiolata directly after emergence from the last larval skin; B. Length $0.90 \mathrm{~mm}$., later stage ; C. Length $1.04 \mathrm{~mm}$., later stage in which all legs are developed; D. Length 1.56 mm., nearly full grown.

moult in which the walking legs are complete, that is to say when the body and legs are fully formed, for a series of measurements show that there is very little difference in the length of the cephalic segment of the young form after it has sloughed its last larval skin and the young form with completely formed legs (see Fig. 3). The increase in length takes place afterwards.

\section{LITERATURE.}

1915. Calman, W. T.-Pyenogonida. British Antarctic ("Terra Nova") Expedition. 1910.

1913. Dogrel, V.-Embryologische Studien an Pantopoden. Zeitschrift für Wissenschaftliche Zoologie, Bd. 107, pp. 575-741.

1864. Hodge, G.-List of the British Pycnogonoidea with Descriptions of Several New Species. Annals and Magazine of Natural History. Feb., 1864.

1881. Нокк, P. P. C.-Nouvelles Etudes sur les Pycnogonides. Archives de Zoologie Expérimentale et Générale, pp. 445-542.

1906. Merton, H.-Eine auf Tethys leporina parasitisch lebende Pantopodenlarve (Nymphon parasiticum, n. sp.). Mittheilungen aus der Zoologischen Station zu Neapel, Bd. 18, pp. 136-41. 
1894. Norman, Canon A. M.-A Month on the Trondhjem Fiord. Annals and Magazine of Natural History, Ser. 6, Vol. XIII. Feb., 1894.

1908. Ibid.-The Podosomata (=Pycnogonida) of the Temperate Atlantic and Arctic Oceans. Journal of the Linnean Society, Zoology, Vol. XXX, pp. 198-238.

1909. Prell, H.-Beiträge zur Kenntnis der Lebensweise einiger Pantopoden. Bergens Museums Aarbog, 1909. No. 10.

1891. SARS, G. O.-Pycnogonidea. Norwegian North Atlantic Expedition, 1876-78. 